Editorial

\title{
Increasing Sustainability of Growing Media Constituents and Stand-Alone Substrates in Soilless Culture Systems-An Editorial
}

\author{
Leo Sabatino \\ Dipartimento Scienze Agrarie, Alimentari e Forestali, University of Palermo viale delle Scienze, \\ Ed. 590128 Palermo, Italy; leo.sabatino@unipa.it; Tel.: +39-091-2386-2252
}

Received: 7 August 2020; Accepted: 10 September 2020; Published: 14 September 2020

\begin{abstract}
Peat-free growing media constituents and stand-alone substrates are the basis for the economic and ecological efficiency of the soilless culture system. Nevertheless, divergence between the model and practice still exists, coming from large gaps in the knowledge of alternative organic materials and of their effects on crop performance. A more detailed understanding of these topics is necessary to increase the soilless culture management capacity. In this respect, the critical review from Nazim Gruda analyses and present research outcomes concerning the sustainability of soilless culture and growing media constituents and their impact on the environment. In particular, the review covers designated articles stressing the pros and cons of soilless culture and growing media constituents, the exploitation of different organic materials and their economic and environmental relevance.
\end{abstract}

Keywords: soilless cultivation system; organic substrates; substrate mixture; plant performance; peat-free growing media

\section{Introduction}

Critical circumstances for sustainable agriculture, such as declining arable land, increasing urbanization, water scarcities, and climate change, exert concern on growers, agronomists, and scientists, as they may injure human and environmental health. Soilless cultivation systems combined with the use of growing media characterized by different constituents or stand-alone substrates represent a fundamental tool to improve plant growth and development and to assure quality yield. Although representing one of the most used organic substrate constituents for soilless cultivation [1], peat moss is a limited resource with a massive demand, and its extraction causes harmful ecological effects [2]. Different organic materials might be employed in order to reduce the $C$ footprint of horticulture production by totally or partly supplanting peat-based substrates [3]. Compost, coir, bark, and wood fiber are some of the organic materials that are currently used in a commercial way as substitutes for peat [4]. Inorganic substrates might also play an important role as support materials in integrated growing closed ecosystems. Vermiculite, perlite, clay granules, lava, and pumice are used as alternatives to rockwool or in a mixture with peat, whereas new organic substrates, such as Sphagnum moss, waste and digestates, biochars, and hydrochars are still in their examination stage.

In view of that, increased acquaintance with potential growing media constituents, stand-alone substrates, or innovative growing procedures is decisive in recovering the environmental sustainability of the agriculture sector.

\section{Paper Overview}

The paper entitled "Increasing Sustainability of Growing Media Constituents and Stand-Alone Substrates in Soilless Culture Systems" was published within the framework of the Special Issue 
"Soilless Culture, Growing Media and Horticultural Plants" edited by Prof. Dr. Nazim Gruda and Dr. Brian Eugene Jackson. The paper is a critical review that assembles contemporary research outcomes dealing with the understanding of the impacts that soilless culture and growing media may have both on the environment and on the sustainability of horticultural practices. In this Editorial I will briefly introduce the review, which concerns imperative subjects of the horticultural sector, comprising: (i) the pros and cons of soilless culture and a critical discussion at the economic and environmental level, of the characteristics of the various growing media and substrates used by this technology; (ii) the exploitation of different organic materials, with the objective to identify effective replacements of peat and rockwool.

\subsection{An Overview on the Pros and Cons of Soilless Culture and Growing Media}

First of all, the author sheds light on the pros and cons of the soilless system and of the different growing media. In this regard, he highlights that the soilless cultivation systems, due to their components (such as the use of heated greenhouses, artificial lighting, greenhouse structure, fertilizers and growing media, postharvest transport, and packaging), are linked with ecological concerns and the production of huge quantities of greenhouse gases. However, the author specifies that according to Mugnozza et al. [5], soilless cultivation decreases the ecological impact by more than double, due to the smaller amount of fertilizers and pesticides released to the environment, compared to soil cultivation. The paper also reports that higher yields at a realistic production cost and high product quality can be accomplished by this technology. Furthermore, saving water and fertilizers saving can be achieved through the use of soilless cultivation systems, especially when the closed-loop system is adopted. On the other hand, the author points out that the main difficulties of soilless cultures are the high investment and energy costs that are mandatory for the initial setup, as well as the increased technical skills.

\subsection{The Exploitation of Different Organic Materials}

In this section, the author emphasizes that diverse organic materials may play a significant role in reducing the $C$ footprint of agriculture-related industries by completely or partially substituting peat-based substrates. In this regard, he arranges different sub-paragraphs in order to collect and discuss in depth the most important current research findings dealing with different benefits derived from the use of organic materials other than peat moss. Particular attention is paid to organic materials such as compost, coir, bark and wood-based materials, biochar, and hydrothermal carbonization products (HCPs). Furthermore, other organic materials, including untransformed waste stream materials, are analyzed. Waste materials comprise rice hulls [6-8], almond shell waste [9-11], hazelnut husks [12-14], and paper waste [15]. Additionally, the review gives specific practical information on growing media choice, disposal concerns, and waste management.

\section{Conclusions}

Soilless cultivation systems are a valuable tool to produce high-quality horticultural products. Furthermore, it is one of the best techniques to overcome several issues related to water shortages, soil problems, and other environmental challenges.

This critical review comprises several articles concerning both the increasing sustainability of growing media constituents and stand-alone substrates in soilless culture systems and the potential use of peat-free substrates in the horticulture production system, therefore filling in the lack of knowledge on alternative organic materials and their effects on crop performance.

I am trustful that this critical review will encourage additional investigations and efforts to find new potential substrates to be used in soilless cultivation systems.

Funding: This research received no external funding.

Conflicts of Interest: The author declare no conflict of interest. 


\section{References}

1. Li, Q.; Chen, J.; Caldwell, R.D.; Deng, M. Cowpeat as a substitute for peat in container substrates for foliage plant propagation. HortTechnology 2009, 19, 340-345. [CrossRef]

2. Maher, M.; Prasad, M.; Raviv, M. Organic soilless media components. In Soilless Culture: Theory and Practice, 2nd ed.; Raviv, M., Lieth, J.H., Eds.; Andre Gerhard Wole: Amsterdam, The Netherlands, 2008; pp. 459-504. Available online: https://books.google.it/books?hl=it\&lr=\&id=6bKPDwAAQBAJ\&oi=fnd\&pg=PP1\&dq= Soilless+culture:+Theory+and + practice\&ots=NXBYiJRr3b\&sig=rtWOQhArGjSaDhF9YnhY4NBmrfk\& redir_esc $=\mathrm{y} \# \mathrm{v}=$ onepage $\& \mathrm{q}=$ Soilless $\% 20$ culture $\% 3 \mathrm{~A} \% 20$ Theory $\% 20$ and $\% 20$ practice $\& \mathrm{f}=$ false $($ accessed on 12 December 2019).

3. Gruda, N.S. Increasing Sustainability of Growing Media Constituents and Stand-Alone Substrates in Soilless Culture Systems. Agronomy 2019, 9, 298. [CrossRef]

4. Gruda, N. Current and future perspective of growing media in Europe. Acta Horticulturae 2012, 960, 37-43. [CrossRef]

5. Mugnozza, G.S.; Russo, G.; De Lucia Zeller, B. LCA methodology application in flower protected cultivation. Acta Horticulturae 2007, 761, 625-632. [CrossRef]

6. Tsakaldimi, M. Kenaf (Hibiscus cannabinus L.) core and rice hulls as components of container media for growing Pinus halepensis M. seedlings. Bioresour. Technol. 2006, 97, 1631-1639. [CrossRef]

7. Gómez, C.; Robbins, J. Pine bark substrates amended with parboiled rice hulls: Physical properties and growth of container-grown Spirea during long-term nursery production. HortScience 2011, 46, 784-790. [CrossRef]

8. Bonaguro, J.E.; Coletto, L.; Zanin, G. Environmental and agronomic performance of fresh rice hulls used as growing medium component for Cyclamen persicum L. pot plants. J. Clean. Prod. 2017, 142, 2125-2132. [CrossRef]

9. Urrestarazu, M.; Martínez, G.A.; del Carmen Salas, M. Almond shell waste: Possible local rockwool substitute in soilless crop culture. Scientia Horticulturae 2005, 103, 453-460. [CrossRef]

10. Arvanitoyannis, I.S.; Varzakas, T.H. Vegetable waste treatment: Comparison and critical presentation of methodologies. Crit. Rev. Food Sci. Nutr. 2008, 48, 205-247. [CrossRef] [PubMed]

11. Valverde, M.; Madrid, R.; García, A.L.; del Amor, F.M.; Rincón, L.F. Use of almond shell and almond hull as substrates for sweet pepper cultivation. Effects of fruit yield and mineral content. Span. J. Agric. Res. 2013, 11, 164-172. [CrossRef]

12. Özçelik, E.; Peks sen, A. Hazelnut husk as a substrate for the cultivation of shiitake mushroom (Lentinul aedodes). Bioresour. Technol. 2007, 98, 2652-2658. [CrossRef] [PubMed]

13. Dede, O.H.; Ozdemir, S. Development of nutrient-rich growing media with hazelnut husk and municipal sewage sludge. Environ. Technol. 2018, 39, 2223-2230. [CrossRef] [PubMed]

14. Dede, O.H.; Dede, G.; Ozdemir, S.; Abad, M. Physicochemical characterization of hazelnut husk residues with different decomposition degrees for soilless growing media preparation. J. Plant Nutr. 2011, 34, 1973-1984. [CrossRef]

15. Chrysargyris, A.; Stavrinides, M.; Moustakas, K.; Tzortzakis, N. Utilization of paper waste as growing media for potted ornamental plants. Clean Technol. Environ. Policy 2018, 21, 1937-1948. [CrossRef]

(C) 2020 by the author. Licensee MDPI, Basel, Switzerland. This article is an open access article distributed under the terms and conditions of the Creative Commons Attribution (CC BY) license (http://creativecommons.org/licenses/by/4.0/). 